\title{
THE FIRST WORKSHOP: New Developmentalism
}

In the first workshop held in São Paulo, in May 24-25, 2010, the Ten Theses on New Developmentalism were originally discussed. Following, is the document that accompanied the invitation of the participants.

With the support of Ford Foundation, the Center for Development Macroeconomics of the School of Economics of São Paulo of Getulio Vargas Foundation will held, on May 24-25 2010, a workshop and in March next year a broader conference on "Growth with financial stability and new developmentalism". In the workshop, the 20 Brazilian and foreign economists that will be invited will be asked to define a list of 10 short theses or policy recommendations that should characterize "new developmentalism" - the national development strategy that middle income countries are supposed to adopt to grow with financial stability. New developmentalism is an expression that several of the participants of the workshop have been using since the early 2000s as a responsible and feasible alternative to the Washington consensus or to conventional orthodoxy. To limit the theses or policy recommendations to 10 is important because the objective is to get out of these project with some reasonably agreed and simple to remember ideas. Personally, I have been using a tripod - exchange rate responsibility or growth with domestic savings, fiscal responsibility, and strategic role for the state - to define new developmentalism, but this approach is oriented to public opinion or to the national agenda that is unable to assume more than three elements of a given theme. In order to be understood to a more restricted number of economists and politicians or of policymakers, I believe that 10 is a reasonable number.

The organizers will propose a provisory list of 10 theses to be discussed. In the workshop we will, first, discuss and define the theses, amending and substituting what is agreed. Second, we will distribute them among ourselves so that each theme will be under the responsibility of two participants. Third, the other participants will offer suggestions to the two participants responsible for the theme. After this, each group of two participants will have a 10 months period to write a small policy paper 
(15 to 20 double space pages). In the second workshop to be held in March 2011 these policy papers will be discussed with a larger group of invited people including Brazilian politicians and policymakers, and with the presence of the media.

Adopting this somewhat heterodox method we are not aiming full agreement, nor writing anything similar to a plan. We are just asking for some agreement on a list of key theses or policy recommendations that characterize a competent national development strategy. We would like to have agreement on the expression "new developmentalism", but this will not be required from anybody. Below we offer a short reference to papers and books that used the expression, and we attach a recent paper by Bresser-Pereira to be published in the Handbook of Latin America Economics that José Antonio Ocampo is editing for Oxford University Press that, in some way, summarize the ideas. We just make reference to articles that used the expression. Without using it, there are a large number of heterodox economists - certainly all the invited to this workshop - that wrote on the subject.

This project has as background, on one hand, the 2008 Global Financial Crisis and, on the other, fast growth in several dynamic Asian countries that, in some way, adopt a new developmentalist national strategy. The most general objective of these two conferences is to discuss how to achieve economic growth in a global framework of financial instability. As most participants are Brazilians and Latin-Americans, the economy of these countries will get more attention. In order to be more specific, the three main concerns will be: (1) to analyze the global financial crisis and its consequences in developing countries; $(2)$ to identify the main characteristics of the repeated financial crises in Latin America in the recent past; and (3) to discuss the policy recommendations that will assure growth with stability.

\section{Financial instability}

The 2008 crisis took the world by surprise, because politicians, businessmen and economists believed that they had learned with 1930s Great Depression. The Keynesian revolution, the strengthening of central banks, the development of full regulatory system, and the creation of the Breton Woods institutions proved such learning. They had a definite objective: to avoid new major financial crises. Yet, since the 1970s, economists engaged in de-learning or forgetting what they have learned. They relegated Keynesian macroeconomics to the margin and deregulated financial markets. In consequence, since the early 1980s financial crises multiplied in the central and in the developing economies, but only in the latter they were disastrous as, for instance, the 1980s Latin-American debt crisis, or the 2001 Argentinean crisis. In the central countries they happened but were relatively mild. But suddenly a banking crisis that began in the United States with the default of subprime mortgages in 2007 turned into bank failures and into panic in October 2009. A consensus was established very soon that this was the worst economic crisis since the 1930s. It will be a crisis that probably will live with us for many years despite the strong and reasonably competent economic policies with which governments responded to it.

In this crisis, developing countries suffered less. All of them saw their growth rates reduced and, in several cases, turned negative, but while all rich countries 
were strongly hit by the crisis, major losses among middle income countries only occurred in the ones that had become highly indebted recently like some East European countries, or, being industrial economies, depended too much on oil exports like Russia, or had their economy too much dependent on the American economy like Mexico. This lighter impact is not surprising in relation to Asia, but it is in relation to Latin America that has a long history of recurrent financial crises. Of particular interest is the fact that banking and financial systems appear to have weathered the crisis without major difficulties.

The global financial crisis as well as the continued and high growth of several Asian countries are having and will have major impacts in Latin America. The continued expansion of developing countries in the East will provide both opportunities and challenges; the instability of the dollar will lead to a search for a more stable international monetary standard; declining global trade flows will make national policies and priorities more important; new regulation for financial markets will be proposed; global financial flows will relatively shrinkas financial institutions become more risk averse and reduce leverage. While all of these changes will have strong impact on Latin-American economies, none of them will be dominated by the response by Latin-American economies to the crisis. The main focus of the project will thus be on the second objective. The assumption or hypothesis is that while financial crises in Latin America have usually involved a crisis in the banking system, problems usually originate in the balance of payments or in borrowing on foreign currency that leads to currency crises. The present crisis differs because it did not start in a developing country, and it seems to have been initiated by the banking system in developed countries. Indeed, financial systems in developing countries appear to have been isolated from the worst effects of the subprime lending bubble. Many Latin-American countries, including Brazil, appear to be recovering from the crisis more rapidly than the developed countries. This raises the question of the impact of the crisis on the banking system in Latin America and whether it has played a major role in the rapid recovery in countries such as Brazil. Indeed, some have suggested that developing countries were unable to decouple from the developed countries in the propagation of the crisis, but that they have been able to do so in the recovery. This will thus be a major focus of the project.

Since most developing countries have followed policies of financing domestic growth by borrowing foreign savings, they have suffered overvaluation of the exchange rate that has supported recurrent and large current account deficits. As debt increases foreign creditors eventually lose confidence, refuse to roll over their loans and the resulting sharp reversal in capital inflows leads to a sharp devaluation of the currency and sovereign and domestic defaults that spread to the domestic financial system. It is this tendency to the overvaluation of the exchange rate that has been a major factor not only in causing balance of payment crisis but also artificially high real wages, artificially high consumption, low domestic savings, and low growth rates and have provided the background for fragility of the domestic financial system.

The project will seek to verify this explanation of recurrent financial crises in Latin America, that is, that they are the result of balance of payment crises that originate in poor lending decisions made by banks of the rich countries, in their 
own currencies, to firms and governments in the developing countries, rather than by the bad lending decisions of domestic banks to lend to domestic borrowers.

Given that financial crises are recurrent in Latin America it will be necessary to ascertain whether there is accompanying regularity in the balance of payment crises. Or, in other words, if developing countries, and, among them, Latin-American countries tend systematically to incur in high foreign indebtedness, following a cycle.

The question is whether this foreign indebtedness and recurrent balance of payment crises derive from the recurrent public deficits or fiscal largess or fiscal populism, as the dominant economic literature asserts, or, alternatively, whether it is the result of repeated current account deficits financed by lending by foreign financial institutions in foreign currency.

It is also necessary to investigate whether the foreign financing of balance of payments imbalances leads to a tendency to the overvaluation of the exchange rate in developing countries. The exchange rate does not fluctuate nicely around the line of intertemporal equilibrium of the current account, as orthodox economists would predict; nor is just volatile, as less orthodox economists widely recognize; but this volatility has a sense: it tends to appreciation or overvaluation.

The use of overvaluation raises the question of the definition of the equilibrium exchange rate. In principle, it should be the exchange rate that produces intertemporal equilibrium in the current account. However, in the presence of the Dutch disease, the real equilibrium exchange rate will be the one that makes competitive industries utilizing state of the art technology or that are on the production efficiency frontier in equilibrium. It is thus necessary to determine the causes of the overvaluation of the exchange rate in developing countries. The project will thus seek explanations of the overvaluation by historical evidence, previous econometric studies and new evidence based on our research.

Given the reversal in the role of the banking system in the current crisis, it will be necessary to identify how domestic banks and financial systems were involved in this process of overvaluation. In addition, it will be necessary to identify if this role has changed in the current response to the crisis. For example, after the crisis of the 1980s the Brazilian financial system underwent a major crisis and government intervention. In the mid 1990s the crisis was not yet solved, and required additional government intervention: the PROER initiative. Since that time it has been extremely stable, withstanding all the crises of the 1990s as well as the recent one with no bank panic or insolvencies. However, in the period of the crisis of 2007-2008, Brazilian and foreign banks were involved in foreign currency speculation that may have contributed to the overvaluation of the exchange rate and to large subsequent losses for domestic businesses.

In this period domestic firms were also offered complex speculative contracts that used out of the money options predicated on the assumption of continued appreciation and overvaluation of the Real. After the Lehman collapse the exchange rate unexpectedly started to depreciate. In two months, from August to October, the exchange rate moves from around 1.60 to 2.30 and eventually to around 2.50 two months later. This is a move of between $40 \%$ and $50 \%$. For an out of the money option that had been written at a strike of 1.70 would have produced a loss 
of Real 3.5 million on a notional contract of R10 million. Or if written at 2X leverage 7 million. The estimates are that companies that bought these contracts such as Aracruz lost \$2,130 million, Grupo Votorantim Diversificado - \$1,040 million and Sadia $-\$ 360$ million.

The existence of these contracts not only created solvency problems for businesses, which is important to the impact of the Dutch disease, but more importantly for the project, the existence of such contracts acted in a pro cyclical manner in the foreign exchange market. Thus, it exacerbates the overvaluation of the currency when it is appreciating and increases the demand for dollars in the domestic money market, creating a sharp increase in demand for dollar liquidity, exacerbating the volatility of the exchange rate.

Since this project involves economic theory and economic policy project, it will involve political scientists as well as international trade, macro and financial market economists to participate because, for instance, in the discussion of the causes of overvaluation and crises related either to excessive lending-borrowing or to exchange rate populism, we are interested also in the political questions involved. Second, when we discuss policy recommendations, we also need political scientists and international relations specialists to participate in the discussion.

\section{New developmentalism}

The extraordinary growth rates of several Asian countries since the 1980s contrast with substantially smaller rates in Latin America. In the 2000s there was some improvement in growth rates in Latin America, but this outcome was not explained by endogenous factors, but by the increase in commodity prices. From the 1930s or, at least, from the 1950s, Latin-American countries adopted a successful national development strategy, namely, national developmentalism, based on development economics and in the Latin-American structuralist economic theory. In the late 1980s, after ten years of foreign debt crisis combined with high rates of inflation, this strategy was replaced by the Washington Consensus or conventional orthodoxy - an imported strategy based on the deregulation of markets, growth with foreign savings, high interest rates and overvalued exchange rates. Ten years later, after the 1994 Mexican, the 1998 Brazilian and the 2001 Argentinean financial crises, the failure of this strategy became evident, as it caused repetitive balance of payment crises and failed to improve living standards. On the other hand, I assume that middle-income developing countries are supposed to grow faster than rich countries and catch up. Financial globalization is a threat to that, but commercial globalization is as opportunity as the Asian experience shows.

Since the early 2000s, Latin-American countries have been once again seeking a national development strategy. In the political realm, this search has been expressed by the successive elections of center-left and nationalist political leaders. Yet the success of this search is not assured, because, on one hand, most of these countries are poor, lack a capable state and very difficult to be governed, and, on the other, because we cannot see national development strategies behind this political change. The poorer a country is, the more unequal and poorly educated will be its people, and more difficult it will be to govern and to formulate appropriate economic policies. 
New developmentalism is a set of values, ideas, institutions, and economic policies through which, in the early 21 st century, middle-income countries seek to catch up with developed countries. It is not an economic theory but a strategy; it is a national development strategy, based mainly on Keynesian macroeconomics and structuralist development macroeconomics. It is the set of ideas that enables developing nations to reject rich nations' proposals and pressures for reform and economic policy, like capital account liberalization and growth with foreign savings. It is the means by which businessmen, government officials, workers and intellectuals can stand together as a true nation to promote economic development. New developmentalism is suitable for middle-income countries rather than for poor countries, not because poor countries do not require a national development strategy, but because their strategies involve accomplishing primitive accumulation and industrial revolution, or, in other words, because the challenges they face are different from those faced by middle-income countries.

The basic propositions behind new developmentalism are macroeconomic; they derive from a structuralist development macroeconomics that is being defined by critical Latin-American economists having as parameter the Asian experience. The supply aspects of economic growth including industrial policy are naturally considered in this approach, but, given its Keynesian and Kaleckian foundation, two tendencies that press down demand - the tendency of wages to increase below the productivity rate and the tendency to the overvaluation of the exchange rate - are crucial to the new ideas. The first derives from the definition of a developing country as a dual economy and from the classic work of Arthur Lewis (1954) showing that developing countries face an unlimited supply of labor - and represents a major impediment to the creation of mass consumption economies in the region. This fact implies a rise in wages when the worker migrates from the traditional sector to the modern sector, but thereafter it presses down wages in the modern sector - which causes increasing inequality and a chronic insufficiency of demand. In the 1970s, in Latin America, this problem was classically "solved" by the production of luxury goods to be consumed by the middle class and the rich, or by exporting wage goods and importing luxury goods and capital goods.

The second structural tendency - the tendency to the overvaluation of the exchange rate - explains why the exchange rate is not eventually controlled by the market, but by balance of payment crises instead or by sudden stops. As conventional economics presupposes that wages are well equilibrated by the labor market, it supposes that the same happens with the exchange rate. Yet, if the exchange rate is left fully free in a developing country, a series of structural and policy factors will lead it to appreciate, the country will incur in current account deficit, will get indebted, will suffer from chronic financial fragility, and, finally, when foreign creditors lose confidence, will face a "sudden stop" - a balance of payment or currency crisis and a sharp devaluation. 